\title{
The Effect of Carbon Dioxide Concentration and Buffer System on Nitrate and Nitrite Assimilation by Dunaliella tertiolecta
}

\author{
By B. R. GRANT \\ Division of Fisheries and Oceanography, CSIRO, Cronulla, \\ N.S.W. 2230, Australia
}

(Accepted for publication 18 July 1968)

SUMMARY

\begin{abstract}
Dunaliella tertiolecta required carbon dioxide in substrate concentrations $(\mathrm{I} \cdot 75 \%, \mathrm{v} / \mathrm{v})$ to assimilate either nitrate or nitrite at maximum rates in light. The addition of glucose, glycerol, acetate, pyruvate or $\alpha$-ketoglutarate did not remove the requirement for carbon dioxide. The rates of nitrate and nitrite assimilation in light depended upon the buffer system used. The lowest rates of nitrate assimilation, $\mathrm{I} \cdot 3 \mu \mathrm{moles} / \mathrm{hr} / \mathrm{mg}$. chlorophyll, were observed in $0.05 \mathrm{M}$-phosphate buffer ( $\mathrm{pH} 7.6$ ) and the highest, $13.7 \mu \mathrm{moles} / \mathrm{hr} / \mathrm{mg}$. chlorophyll, in $0.05 \mathrm{M}$-Tricine buffer $(\mathrm{pH} 7 \cdot 6)$. Nitrite assimilation was lowest, $7.5 \mu \mathrm{moles} / \mathrm{hr} / \mathrm{mg}$. chlorophyll, in $0.05 \mathrm{M}$-phosphate $(\mathrm{pH} \mathrm{7.6)}$ while the highest rates, $18.7 \mu \mathrm{moles} / \mathrm{hr} / \mathrm{mg}$. chlorophyll, were observed in $0.05 \mathrm{M}$-Tricine (pH 8.6). The low rate of assimilation of nitrate and nitrite in $0.05 \mathrm{M}$-phosphate buffer $(\mathrm{pH} 7.6$ ) was increased by diluting the buffer to $0.005 \mathrm{M}$, at this concentration the rate in phosphate buffer was comparable to that in tris or Tricine buffers at the same $\mathrm{pH}$ values. Buffer type had little effect on either nitrate or nitrite assimilation in the dark. There was no evidence with any buffer system used for the evolution of extra oxygen associated with nitrate or nitrite assimilation in the light. These results provide further evidence for the existence of two independent systems of nitrate reduction, one within and the other without the chloroplast. In addition, they indicate that in Dunaliella tertiolecta the enzyme system which fixes carbon dioxide is unlikely to be the rate-limiting step in photosynthesis.
\end{abstract}

\section{INTRODUCTION}

Some algae, Scenedesmus (Bongers, 1958), Chlorella (Davis, 1953) and Anabaena (Hattori, 1962) evolve oxygen at greater rates during nitrate and nitrite assimilation in light than under otherwise similar conditions when these anions are absent. The extra oxygen bears a stoichiometric relationship to the nitrate or nitrite assimilated. However, the green alga Dunaliella tertiolecta, although showing a large increase in both nitrate and nitrite assimilation in light, did not show the stoichiometric evolution of extra oxygen found in other algae (Grant, 1967). Furthermore, Dunaliella required carbon dioxide in order to show any increase in nitrate or nitrite assimilation in light. The present paper examines this requirement for carbon dioxide and explores the effect of different buffer systems on nitrate and nitrite assimilation and the oxygen evolution associated with it. 


\section{METHODS}

Organism and culture methods. The strain of Dunaliella tertiolecta (Butcher) was the same as used previously (Grant, 1967), as were the culture media and methods, except that $48 \mathrm{hr}$ cultures were used, not $72 \mathrm{hr}$ cultures. The organisms from the $48 \mathrm{hr}$ culture gave consistently higher rates of nitrate and nitrite assimilation in light, although the dark assimilation rates were either unchanged or only slightly lower.

Preparation of suspensions of organisms. Organisms were harvested and concentrated as previously (Grant, 1967) except that an artificial sea water instead of $3 \% \mathrm{NaCl}$ was used to wash and resuspend organisms after centrifugation. The artificial sea water contained (g./1.): $\mathrm{NaCl}, 20.9 ; \mathrm{Na}_{2} \mathrm{SO}_{4}, 3.9 ; \mathrm{KCl}, 0.7 ; \mathrm{NaBr}, 0.1 ; \mathrm{H}_{3} \mathrm{BO}_{3}, 0.03$.

Chlorophyll determination. Chlorophyll was extracted from organisms in a sample of suspension after centrifugation for $2 \mathrm{~min}$. at $1000 \mathrm{~g}$. Extraction with $2 \mathrm{ml}$. portions of $100 \%$ acetone at room temperature was continued until no further pigment was released and the residue was colourless. The acetone extract was diluted with distilled water to $90 \%(\mathrm{v} / \mathrm{v})$ immediately before determining the extinction at 665 and $645 \mathrm{~m} \mu$ and the concentration of chlorophylls $a$ and $b$ was then calculated by using the equation of Humphrey \& Jeffrey (in preparation). Where chlorophyll is referred to subsequently it means $a+b$. The use of $100 \%$ acetone, although less satisfactory than $90 \%$ acetone as an extracting solvent, prevented the action of chlorophyllase (Barrett \& Jeffrey, 1964).

Packed cell volume was determined by centrifuging a sample of organism suspension in a haematocrit tube at $3000 \mathrm{~g}$ for $60 \mathrm{~min}$.

Dry weight was determined by centrifuging a sample of organism suspension in a conical centrifuge tube for $5 \mathrm{~min}$. at $1000 \mathrm{~g}$, and after carefully removing the supernatant fluid with a Pasteur pipette, resuspending the pellet in distilled water and transferring to a tared vial. The suspension was dried overnight at $45^{\circ}$ in a vacuum oven and weighed after storage for $2 \mathrm{hr}$ over $\mathrm{P}_{2} \mathrm{O}_{5}$ in a desiccator.

Numbers of organisms were determined by direct counting on a Petroff-Hauser counter.

Nitrate and nitrite were determined as in Grant (1967), except when phosphate was present. The phosphate was removed by adding to each ml. of supernatant fluid (containing $\sim 50 \mu$ moles phosphate) $100 \mu$ moles magnesium sulphate and $200 \mu$ moles ammonium hydroxide. The resulting precipitate was centrifuged down and a sample of the supernatant fluid passed through the cadmium reducer. Failure to remove phosphate resulted in rapid destruction of the cadmium + mercury reducer and erratic reduction of nitrate.

Oxygen evolution and uptake were measured in a respirometer at $20^{\circ}$, illuminated as required from below by incandescent lamps which gave at the lower surface of the vessel an energy of $27 \mathrm{~mW} / \mathrm{cm}^{2}$ between 400 and $750 \mathrm{~nm}$, with a peak at $675 \mathrm{~nm}$. This was above the intensity required to saturate photosynthesis under these conditions.

Where carbon dioxide was not provided by bicarbonate + carbonate mixtures as an internal $\mathrm{pH}$ and $\mathrm{CO}_{2}$ buffer, it was supplied by adding carbonate + bicarbonate mixtures to the trough of the manometer flask as described by Warburg \& Krippahl (1959, 1960). Carbonic anhydrase (I $\mu \mathrm{g} . / \mathrm{ml}$.) was added to both trough and vessel contents in experiments when carbon dioxide was maintained below a partial pressure 
of $7.5 \mathrm{~mm}$. mercury. Above this value carbonic anhydrase was not used because it did not increase the rate of oxygen evolution.

Buffers. Tris and Tricine buffers were prepared in distilled water and the $\mathrm{pH}$ value adjusted with $\mathrm{HCl}$. Bicarbonate + carbonate buffer used internally was artificial sea water (composition given above) containing $0.035 \mathrm{M}-\mathrm{K}_{2} \mathrm{CO}_{3}$ and $0.065 \mathrm{M}-\mathrm{NaHCO}_{3}$. The external carbon dioxide buffers were carbonate and bicarbonate mixtures prepared in distilled water as described by Warburg \& Krippahl (1959).

\section{RESULTS}

\section{Effect of culture age}

In batch culture the rate at which Dunaliella tertiolecta assimilated nitrate in light and the rate at which oxygen was evolved decreased rapidly as the culture aged.(Fig. 1). This rapid decrease in activity was not due to exhaustion of nitrate in the medium since after 4 days one-third of the total nitrate supplied still remained. Some of the decrease may have been due to a decrease in chlorophyll content of the organisms (Madgwick, 1966). This rapid change in activity made comparison of assimilation rates in different species difficult. However, in the present experiments, when the cultures were used at exactly the same age and grown under identical conditions, organisms of uniform composition and similar nitrate and nitrite assimilating activity were obtained. These organisms had the following properties: cell weight $5^{8} \pm 8 \mu \mu \mathrm{g}$.; packed cell volume $2 \mathrm{I} 8 \pm 29 \mu^{3}$; chlorophyll content $\mathrm{I} \cdot 06 \pm 0 \cdot \mathrm{I} 3 \mu \mu \mathrm{g}$; ; total nitrogen content $4 \cdot 6 \pm 0 \cdot \mathrm{I} \mu \mu \mathrm{g}$
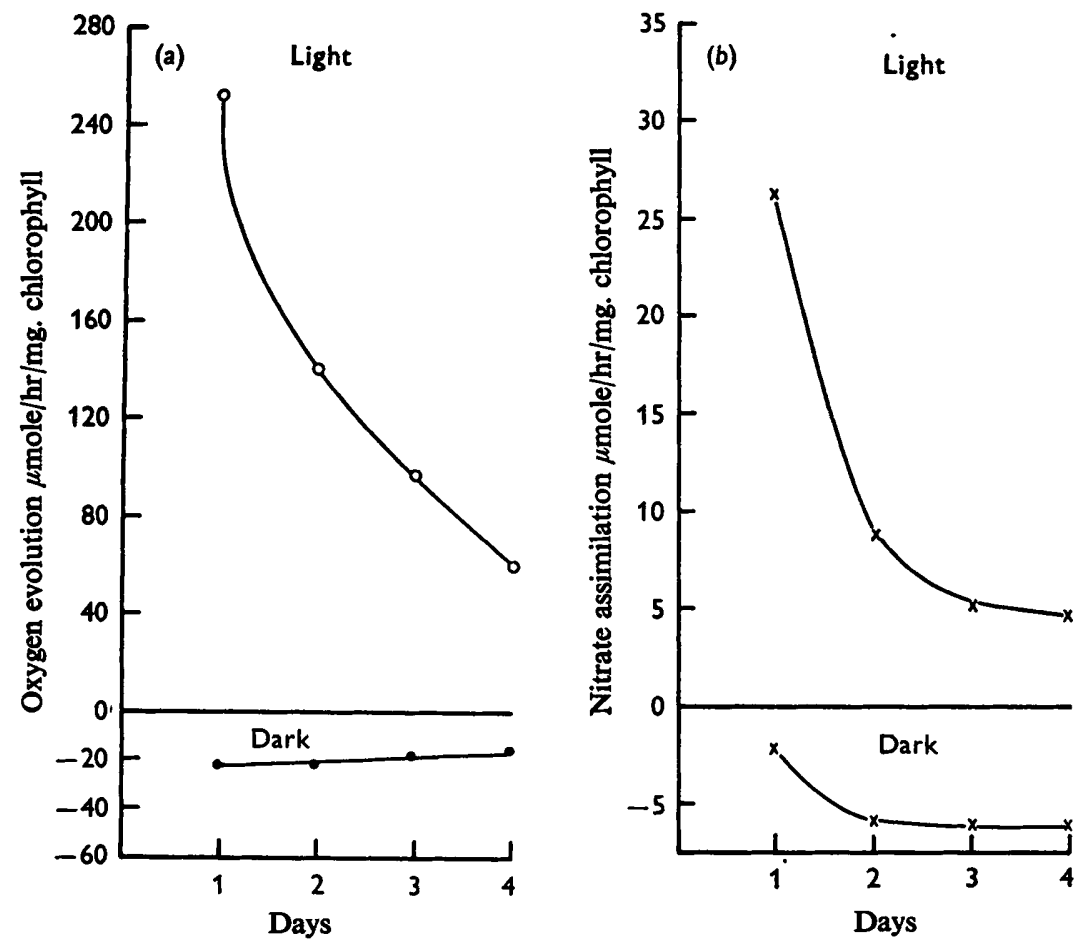

Fig. I. Change in activity of cells with age. 


\section{Carbon dioxide requirement}

When the carbon dioxide concentration in the gas phase was varied over a partial pressure range of o to $35 \mathrm{~mm}$. mercury $(0$ to $4.5 \%, \mathrm{v} / \mathrm{v})$ the rates of nitrate and nitrite assimilation followed a parallel course to that of oxygen evolution (Fig. 2). At low partial pressures of carbon dioxide it was difficult to maintain constant rates of oxygen evolution for more than $20 \mathrm{~min}$., even with low concentrations of organisms and carbonic anhydrase present. However, the results showed that nitrate and nitrite assimilation rates in the light required more than catalytic amounts of carbon dioxide to be present and that the concentrations required for maximum rates of oxygen evolution and those required for maximum assimilation in light of nitrate and nitrite were very similar. In the dark, variation in carbon dioxide concentration had no effect.

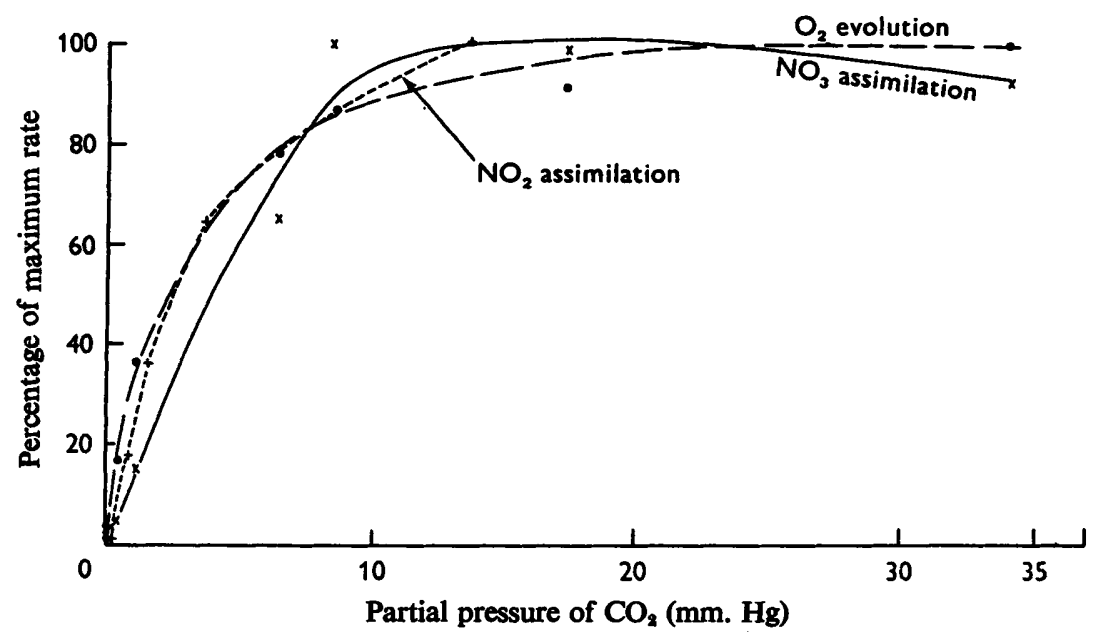

Fig. 2. $\mathrm{NO}_{8}$ assimilation, $\mathrm{NO}_{8}$ assimilation, and $\mathrm{O}_{2}$ evolution as a function of $\mathrm{CO}_{2}$ partial pressure. Maximum rates: $135 \mu$ mole $\mathrm{O}_{2} / \mathrm{hr} / \mathrm{mg}$. chlorophyll, $13.0 \mu$ mole $\mathrm{NO} / \mathrm{hr} / \mathrm{mg}$. chlorophyll, $12.5 \mu$ mole $\mathrm{NO}_{2} / \mathrm{hr} / \mathrm{mg}$. chlorophyll.

\section{Effect of added compounds}

The addition of a variety of low molecular weight organic compounds did not increase the rate at which either nitrate or nitrite was assimilated in the light in absence of carbon dioxide (Table I). Glycerol, acetate and $\alpha$-ketoglutarate in fact decreased the nitrate assimilation rate below that observed in the control vessels to which no addition was made; glucose and glycerol had a similar effect on nitrite assimilation. In darkness glucose caused a small increase in the rate of assimilation of nitrate; the other compounds decreased the rate or had no effect. Where these substances were added in the presence of $\mathrm{CO}_{2}$ no significant effect on nitrate or nitrite assimilation was noted. Experiments with [U-14 C]glucose (specific activity $3 \times 10^{4} \mathrm{dpm} / \mu \mathrm{mole}$ ) and $\left[\mathrm{U}-{ }^{14} \mathrm{C}\right]-$ acetate (specific activity $\mathrm{I} \times 10^{6} \mathrm{dpm} / \mu \mathrm{mole}$ ) showed that Dunaliella tertiolecta incorporated less than $12 \mu \mu$ mole glucose $/ \mathrm{hr} / \mathrm{mg}$. chlorophyll but that it incorporated acetate at a rate almost 50 times as great. 
Table I. Effect of organic compounds on the rate of nitrate and nitrite assimilation in the absence of carbon dioxide by Dunaliella tertiolecta

Each vessel contained in a total of $2.0 \mathrm{ml}$. : tris $+\mathrm{HCl}$ buffer $(\mathrm{pH} 7 \cdot 6) 100 \mu$ mole; $\mathrm{KNO}_{3}$, $2.0 \mu$ mole; and organisms containing $0.2 \mathrm{mg}$. chlorophyll. Addition of substrate or bicarbonate where indicated was $50 \mu$ mole and, except in vessels containing bicarbonate, $0.1 \mathrm{ml}$. of $20 \% \mathrm{KOH}$ was added to the centre well of each vessel. All values are expressed in $\mu \mathrm{mole} /$ hr/mg. chlorophyll.

No addition
D-Glucose
$\alpha$-Ketoglutarate
Glycerol
Acetate
Pyruvate
Glutamate
Bicarbonate

$\begin{array}{cc}\text { Light } & \text { Dark } \\ \mathbf{I} \cdot \mathbf{I} & \mathbf{I} \cdot 3 \\ \mathbf{I} \cdot 0 & \mathbf{1} \cdot 8 \\ 0.4 & 0.7 \\ 0.0 & 0.6 \\ 0.3 & 0.6 \\ \mathbf{I} \cdot 2 & 0.8 \\ \mathbf{I} \cdot 2 & 0.6 \\ \mathbf{I 4} \cdot 6 & \mathrm{I} \cdot 3\end{array}$

\begin{tabular}{cc} 
Nitrite assimilation \\
\hline Light & Dark \\
$2 \cdot 0$ & $1 \cdot 0$ \\
0.5 & $I \cdot 0$ \\
$2 \cdot 0$ & $1 \cdot 0$ \\
0.0 & $I \cdot 0$ \\
- & - \\
- & - \\
- & -
\end{tabular}

Effect of $p H$ value and buffer system

Table 2 shows the effect of four buffer systems at various $\mathrm{pH}$ values on nitrate assimilation, nitrite assimilation and oxygen evolution. In general nitrate and nitrite assimilation responded in the same way, but oxygen evolution did not always change similarly. Nitrite did not accumulate either in organisms or medium under any of the

\section{Table 2. Dunaliella tertiolecta: effect of buffer type on nitrate assimilation}

Conditions as described in text; all values in $\mu \mathrm{mole} / \mathrm{hr} / \mathrm{mg}$. chlorophyll. Chlorophyll in each vessel was 0.05 to $0.1 \mathrm{mg}$. Final buffer concentration $0.05 \mathrm{M}$, and initial concentration of $\mathrm{KNO}_{3}$ or $\mathrm{KNO}_{2}$ was $\mathrm{IO}^{-3} \mathrm{M}$.

\begin{tabular}{|c|c|c|c|c|}
\hline \multirow[b]{2}{*}{ Buffer } & \multirow[b]{2}{*}{$\mathrm{pH}$ value } & \multicolumn{2}{|c|}{ Nitrate assimilation } & \multirow{2}{*}{$\begin{array}{c}\text { Oxygen } \\
\text { evolution }\end{array}$} \\
\hline & & Light & Dark & \\
\hline Phosphate & $7 \cdot 6$ & $1 \cdot 3$ & $1 \cdot 7$ & 262 \\
\hline Tris & $7 \cdot 6$ & $10 \cdot 3$ & 0.9 & 305 \\
\hline Tricine & $7 \cdot 6$ & $13 \cdot 7$ & $1 \cdot 4$ & 278 \\
\hline Tris & $8 \cdot 6$ & 10.5 & 0.4 & 214 \\
\hline Tricine & $8 \cdot 6$ & II $\cdot$ I & 0.3 & 231 \\
\hline \multirow[t]{3}{*}{ Bicarbonate } & $8 \cdot 6$ & $8 \cdot 7$ & 0.3 & I8I \\
\hline & & \multicolumn{2}{|c|}{ Nitrite assimilation } & \\
\hline & & Light & Dark & \\
\hline Phosphate & $7 \cdot 6$ & $7 \cdot 5$ & $3 \cdot 8$ & 290 \\
\hline Tris & $7 \cdot 6$ & $15 \cdot 0$ & 0.0 & 315 \\
\hline Tricine & $7 \cdot 6$ & $15 \cdot 0$ & 3.4 & 276 \\
\hline Tris & $8 \cdot 6$ & $13 \cdot 3$ & 0.6 & 260 \\
\hline Tricine & $8 \cdot 6$ & $18 \cdot 7$ & $0 \cdot 1$ & 260 \\
\hline Bicarbonate & $8 \cdot 6$ & $14 \cdot 5$ & $0 \cdot 1$ & 248 \\
\hline
\end{tabular}

conditions tested, nor was free ammonia detected (lower limit of detection $2.5 \mu \mathrm{g}$. $\mathrm{NH}_{3}-\mathrm{N} / \mathrm{ml}$.) following nitrate or nitrite assimilation. Therefore it was concluded that all nitrate or nitrite assimilated by Dunaliella tertiolecta was reduced to cell nitrogen. The maximum rates of nitrate and nitrite assimilation occurred in Tricine buffer at pH 7.6 and $8 \cdot 6$, respectively, and the minimum in phosphate buffer at $\mathrm{pH} 7 \cdot 6$. Values 
over the range of $\mathrm{pH}_{4.8}$ to 9.2 had little effect on assimilation rates, except in phosphate buffer where a sharp maximum at $\mathrm{pH} 6.5$ was observed. This disappeared when the concentration of buffer was decreased from $0.05 \mathrm{M}$ to $0.005 \mathrm{M}$. Oxygen evolution was not decreased in phosphate buffer, but both oxygen evolution and nitrate assimilation were decreased in bicarbonate buffer by $20 \%$.

\title{
The effect of nitrate and nitrite assimilation on oxygen evolution in different buffer systems
}

Although the buffer type and concentration affected the over-all rate of nitrate and nitrite assimilation there was no detectable increase in oxygen evolution during either nitrate or nitrite assimilation in any of the systems examined. Since the amount of $\mathrm{O}_{2}$ evolved during the experiment did not exceed $20 \mu$ mole and since agreement between replicates was always better than $5 \%$ for $\mathrm{NO}_{3}$ or $\mathrm{NO}_{2}$ estimation and for $\mathrm{O}_{2}$ evolution, the extra oxygen production would have been detectable for any amount of nitrate assimilation in excess of $0.5 \mu$ mole and any nitrite assimilation in excess of $0.66 \mu$ mole, provided that the $2 \cdot 0: I$ and $I \cdot 5: I$ ratios as predicted, held. In fact the differences observed in $\mathrm{O}_{2}$ evolution between controls and vessels containing nitrate or nitrite were well within this $5 \%$ value. (Table 3 ).

\section{Table 3. Dunaliella tertiolecta: effect of nitrate and nitrite on oxygen evolution in different buffer systems}

\begin{abstract}
All values are in $\mu$ mole and are those recorded after $\mathrm{I} \mathrm{hr}$. Nitrate and nitrite assimilation measurements differed in each experiment and batch of organisms. Each vessel contained $\sim 0.075 \mathrm{mg}$. chlorophyll and initial concentration of nitrate or nitrite was $10^{-8} \mathrm{M}$. Final concentration of buffer was $0.05 \mathrm{M}$.
\end{abstract}

\begin{tabular}{|c|c|c|c|c|c|c|c|}
\hline \multirow[b]{2}{*}{ Buffer } & \multirow{2}{*}{$\underset{\text { value }}{\mathrm{pH}}$} & \multicolumn{2}{|c|}{ Oxygen evolved } & \multirow{2}{*}{$\begin{array}{l}\text { Nitrate } \\
\text { assimi- } \\
\text { lated }\end{array}$} & \multicolumn{2}{|c|}{ Oxygen evolved } & \multirow{2}{*}{$\begin{array}{l}\text { Nitrite } \\
\text { assimi- } \\
\text { lated }\end{array}$} \\
\hline & & $+\mathrm{NO}_{3}$ & $-\mathrm{NO}_{3}$ & & $+\mathrm{NO}_{2}$ & $-\mathrm{NO}_{2}$ & \\
\hline $\begin{array}{l}\text { Tris } \\
\text { Tricine } \\
\text { Bicarbonate }\end{array}$ & $\begin{array}{l}8 \cdot 6 \\
8 \cdot 6 \\
8 \cdot 6\end{array}$ & $\begin{array}{l}18 \cdot 3 \\
20 \cdot 1 \\
15 \cdot 3\end{array}$ & $\begin{array}{l}18.3 \\
19.6 \\
15.6\end{array}$ & $\begin{array}{l}0.9 \\
1 \cdot 0 \\
0.8\end{array}$ & $\begin{array}{l}20 \cdot 4 \\
22 \cdot 1 \\
1 \mathrm{I} \cdot \mathrm{I}\end{array}$ & $\begin{array}{l}21 \cdot 0 \\
21 \cdot 5 \\
11 \cdot 7\end{array}$ & $\begin{array}{l}I \cdot 43 \\
I \cdot 4 I \\
0.80\end{array}$ \\
\hline $\begin{array}{l}\text { Tris } \\
\text { Tricine }\end{array}$ & $\begin{array}{l}7 \cdot 6 \\
7 \cdot 6\end{array}$ & $\begin{array}{l}13 \cdot 6 \\
12 \cdot 4\end{array}$ & $\begin{array}{l}13 \cdot 0 \\
12.0\end{array}$ & $\begin{array}{l}0.7 \\
1 \cdot 0\end{array}$ & $\begin{array}{l}22 \cdot 0 \\
19 \cdot 9\end{array}$ & $\begin{array}{l}21 \cdot 4 \\
19 \cdot 6\end{array}$ & $\begin{array}{l}1 \cdot 28 \\
1 \cdot 73\end{array}$ \\
\hline $\begin{array}{l}\text { Phosphate } \\
\text { Phosphate } \\
\text { Phosphate }\end{array}$ & $\begin{array}{l}7 \cdot 6 \\
6 \cdot 5 \\
4 \cdot 8\end{array}$ & $\begin{array}{l}12 \cdot 9 \\
12 \cdot 2 \\
10 \cdot 6\end{array}$ & $\begin{array}{l}13 \cdot 2 \\
11 \cdot 8 \\
10.6\end{array}$ & $\begin{array}{l}0.7 \\
I \cdot 0 \\
0.4\end{array}$ & $\begin{array}{c}6 \cdot 7^{*} \\
19 \cdot 8 \\
5 \cdot 2^{*}\end{array}$ & $\begin{array}{l}22 \cdot 2 \\
18 \cdot 5 \\
17 \cdot 6\end{array}$ & $\begin{array}{l}0.60 \\
I \cdot 20 \\
0.70\end{array}$ \\
\hline
\end{tabular}

* In these experiments oxygen evolution ceased after 10 min. but, in other experiments, when phosphate concentration was decreased to $0.01 \mathrm{M}$ the $\mathrm{O}_{2}$ evolution rate was restored to that of the $-\mathrm{NO}_{2}$ control.

\section{Formation of extra carbon dioxide during dark assimilation of nitrate and nitrite}

Measurements of oxygen uptake and carbon dioxide evolution in the presence and absence of nitrate and nitrite were made in phosphate and Tris buffer only. Extra carbon dioxide was evolved during the assimilation of nitrate and nitrite and, with the exception of phosphate buffer at $\mathrm{pH}_{4} \cdot 8$, the results agreed well with th $2 \cdot 0: \mathrm{I}$ molar ratio for extra $\mathrm{CO}_{2}$ evolved to nitrate assimilated, and the $1 \cdot 5: \mathrm{I}$ ratio for nitrite found by Warburg \& Negelein (1920) with Chlorella. 


\section{DISCUSSION}

Since in these experiments nitrate and nitrite assimilation were affected in a similar manner, in the following discussion nitrate assimilation alone will be referred to and nitrite assimilation implied unless specifically mentioned. It is clear from these results that Dunaliella tertiolecta requires substrate amounts of $\mathrm{CO}_{2}$ to exhibit an increase in $\mathrm{NO}_{3}$ assimilation in light. The amounts needed are more than the catalytic requirement to allow maximum rates of phostosynthetic electron transport such as has been shown in chloroplasts isolated from higher plants (Good, 1963, 1965). Reduced carbon skeletons supplied exogenously do not substitute even in part for $\mathrm{CO}_{2}$. The ineffectiveness of glucose in this respect might be due to the inability of $D$. tertiolecta to assimilate this common metabolite in light or dark, in which it differs from Chlorella (RodriguezLopez, I966; Hulsen \& Prenzel, 1966) and Scenedesmus (Taylor, I950). However, acetate is taken up by $D$. tertiolecta and the results of Craigie \& McLachlan (1964) indicate that the organisms should be permeable to glycerol. The failure of these potential sources of endogenous $\mathrm{CO}_{2}$ and skeletons for amination to replace externally supplied $\mathrm{CO}_{2}$ indicates a close association or coupling of photosynthetic carbon reduction and photosynthetic nitrate reduction.

Nitrate assimilation in light was not accompanied by extra oxygen evolution, although the intensity of light supplied was well above that necessary to saturate photosynthesis. This held true over a range of $\mathrm{pH}_{4.5}$ to 9.2 and in four different buffer systems. It seems, therefore, that it is a characteristic of Dunaliella tertiolecta and is not restricted to special experimental conditions. Previous work (Grant, 1967) showed some oxygen evolution during $\mathrm{NO}_{3}$ assimilation although the amounts had no relationship to $\mathrm{NO}_{3}$ assimilated. These experiments with younger organisms which assimilate $\mathrm{NO}_{3}$ and $\mathrm{NO}_{2}$ up to five times more rapidly confirm that the two processes of $\mathrm{O}_{2}$ evolution and $\mathrm{NO}_{3}$ assimilation are not closely related. In this respect $D$. tertiolecta differs from Chlorella pyrenoidosa (Van Niel, Allen \& Wright, 1953) Ankistrodesmus braunii (Kessler, 1953, 1964) and Anabaena cylindrica (Hattori, 1962). In darkness, nitrate and nitrite assimilation by $D$. tertiolecta both give increased amounts of $\mathrm{CO}_{2}$ evolution. The extra $\mathrm{CO}_{2}$ evolved is in a $2 \cdot 0: \mathrm{I} \cdot 0$ ratio to $\mathrm{NO}_{3}$ assimilated and a I.5: $1 \cdot 0$ ratio to nitrite assimilated. Therefore in the dark, nitrate reduction resembles that reported in other species of algae (Warburg \& Negelein, 1920; Cramer \& Myers, 1949; Syrett, 1955).

The buffer system chosen for measurement of $\mathrm{NO}_{3}$ or $\mathrm{NO}_{2}$ assimilation had a significant effect on the rate observed, although $\mathrm{pH}$ alone did not. Phosphate buffer in particular depressed assimilation rates in light under conditions where either $\mathrm{HPO}_{4}{ }^{2-}$ or $\mathrm{H}_{2} \mathrm{PO}_{4}{ }^{-}$ions were present in high concentration. Similar, although much smaller, effects were observed in tris and bicarbonate buffers. It was outside the scope of this work to investigate the cause of this effect, but when nitrate assimilation by different species of algae is to be compared, preliminary investigation of the buffer system effects should be made.

On the basis of studies with whole organisms of a few species of algae and higher plant chloroplasts, two theories for the action of light on nitrate assimilation have been proposed. One proposes that light and dark reduction proceed by the same mechanism, and the increased rate in light is due to more carbohydrate being available for breakdown, thus providing more reduced pyridine nucleotide. The other assumes 
that the increase in pyridine nucleotide (or ferredoxin or flavoprotein) reduction is brought about directly by photosynthetic electron transport, and that this then reduces nitrate directly. Evidence for each of these theories and their shortcomings have been discussed by Kessler (1964). The results obtained with Dunaliella tertiolecta cannot be explained by either theory without modification. It is unlikely, in this organism, that the rate of pyridine nucleotide production by dark respiration could be increased 2o-fold by an increase in carbohydrate supply, even though $\mathrm{CO}_{2}$ is a pre-requisite for increased rates of nitrate assimilation in light. The difference observed in the sensitivity of light and dark assimilation to iodoacetate (Grant, 1967) is also an indication that different processes are involved. The photo-respiratory system operative in some higher plants (Forrester, Krotkov \& Nelson, 1966) appears to have a maximum of three times the normal dark respiratory rate and therefore could not supply a 20-fold increase in assimilation rate. It is concluded from these results that the effect of light, even though dependent on $\mathrm{CO}_{2}$, does not act by increasing pyridine nucleotide reduction by an increased rate of respiration.

The dependence on $\mathrm{CO}_{2}$, the relatively low light intensity required to saturate both nitrate and nitrite assimilation in Dunaliella tertiolecta (Grant, 1967), and also in Anabaena (Hattori, 1962) and Scenedesmus (Bongers, 1958), and the absence of extra oxygen evolution during nitrate assimilation in light, show that the action of light on nitrate assimilation is more complex in vivo than the simple schemes proposed by Losada, Ramirez, Paneque \& del Campo (1965) and by Joy \& Hageman (1966) from their work with cell-free systems of higher plant chloroplasts. The magnitude of the increase in nitrate assimilation in light shows that the reduction is closely associated with photosynthetic electron flow. If there were a close association between the photosynthetic nitrate-reducing system and the photosynthetic carbon-reducing system, as would be predicted if both these processes took place wholly within the chloroplast, nitrate and nitrite reduction in light could be controlled by feedback inhibition of an intermediate further along in the reductive sequence. Since $D$. tertiolecta does not accumulate ammonia in vivo even under conditions of low $\mathrm{pH}$ value and low $\mathrm{CO}_{2}$ partial pressure, it seems that such a control system does operate in vivo. The failure of acetate, $\alpha$-ketoglutarate and glycerol to replace $\mathrm{CO}_{2}$ may be due to failure to penetrate the chloroplast membrane. Therefore, the evidence from whole organisms of $D$. tertiolecta is consistent with the existence of two separate systems for nitrate assimilation. One system apparently is located completely within the chloroplast, is dependent on $\mathrm{CO}_{2}$ and light, and is insensitive to respiratory inhibitors such as iodoacetate. This probably corresponds to the system investigated by Losada et al (1965) and by Joy \& Hageman (1966) which depends on ferredoxin, for the nitrite reduction step. However, it seems that the final step in which the amino group is transferred to the carbon skeleton must also take place within the chloroplast, in which respect the Dunaliella differs from maize chloroplasts (Ritenour, Joy, Bunning \& Hageman, I967). The second system, which probably corresponds to that occurring in higher plant roots, is outside the chloroplast and depends on respiration for reduced pyridine nucleotide, and is thus sensitive to iodoacetate inhibition.

Because Dunaliella tertiolecta did not evolve extra oxygen when assimilating nitrate or nitrite in light, extra oxygen evolution is not an inescapable consequence of nitrate reduction by the light-activated system. This is additional evidence for the view put forward by Gibbs, Bamberger, Ellyard \& Everson, (1967) that the carbon dioxide 
fixation step is not invariably the rate limiting one in photosynthesis. The results of Homann \& Schmid (1967), with chloroplasts isolated from mutant varieties of tobacco, provide further experimental evidence for this view. Therefore the evolution of extra $\mathrm{O}_{2}$ during light-activated nitrate reduction will depend on the relative activities of the $\mathrm{CO}_{2}$ fixing enzyme system and the photosynthetic electron transporting enzyme system. Scenedesmus (Bongers, 1958) resembles $D$. tertiolecta in this regard. Therefore there is no longer any basis for seeking for stoichiometric ratios between extra $\mathrm{O}_{2}$ evolution and nitrate assimilation in systems assimilating either nitrate or nitrite in light.

\section{REFERENCES}

BARRETT, J. \& JEFFrey, S. W. (I964). Chlorophyllase and formation of an atypical chlorophyllide in marine algae. Pl. Physiol., Lancaster 39, 44.

BONGERS, L. H. J. (1958). Kinetic aspects of nitrate reduction. Neth. J. agric. Sci. 6, 79.

CraigIE, J. S. \& MCLACHLAN, J. (1964). Glycerol as a photosynthetic product in Dunaliella tertiolecta. Can. J. Bot. 41, 317.

Cramer, M. \& MYers, J. (1949). Nitrate reduction and assimilation in Chlorella. J.gen. Physiol. 32, 92.

Davis, E. A. (1953). Nitrate reduction by Chlorella. Pl. Physiol., Lancaster 28, 539.

Forrester, M., Krotkov, G. \& Nelson, D. (1966). The effect of oxygen on photosynthesis, photorespiration and respiration in detached leaves. I. Soybean. Pl. Physiol., Lancaster 4r, 422.

Gibbs, M., Bamberger, E. S., Ellyard, P. W. \& Everson, G. (1967). Assimilation of carbon dioxide by chloroplast preparations. In Biochemistry of Chloroplasts. Ed. by T. W. Goodwin, Vol. 2 , p. 3. London: Academic Press.

Good, N. E. (1963). Carbon dioxide and the Hill reaction. Pl. Physiol., Lancaster 38, 298.

GooD, N. E. (1965). Interpretations of the carbon dioxide dependence of the Hill reaction. Can. J. Bot. 43, 119.

GraNT, B. R. (1967). The action of light on nitrate and nitrite assimilation by the marine chlorophyte Dunaliella tertiolecta (Butcher). J. gen. Microbiol. 48, 379.

HATTORI, A. (1962). Light induced reduction of nitrate, nitrite and hydroxyalamine in a blue-green alga, Anabaena cylindrica. Pl. Cell Physiol., Tokyo 3, 355.

HomanN, P. H. \& ScHMm, G. H. (1967). Photosynthetic reactions of chloroplasts with unusual structures. Pl. Physiol., Lancaster 42, 16r9.

Hulsen, W. \& Prenzel, U. (I966). Úber die Aufnahme verschiedener Zucker durch Chlorella pyrenoidosa. Z. Naturf. 216, 500.

JoY, K. W. \& HAGEMAN, R. H. (I966). The purification and properties of nitrite reductase from higher plants and its dependence on ferredoxin. Biochem. J. Ioo, 263.

KessLer, E. (1953). Über den Mechanismus der Nitratreduktion von Grünalgen. I. Nitritbildung und Nitritreduktion durch Ankistrodesmus braunii. Flora, Jena 76, 280.

Kessler, E. (1964). Nitrate assimilation in plants. A. Rev. Pl. Physiol. 15, 57.

Losada, M., Ramirez, J. M., Paneque, A. \& Del Campo, F. F. (1965). Light and dark reduction of nitrate in a re-constituted spinach chloroplast system. Biochim. biophys. Acta ro9, 86.

MADGwicK, J. C. (1966). Chromatographic determination of chlorophylls in algal cultures and phytoplankton. Deep Sea Res. 13, 459.

RITENouR, G. L., JoY, K. W., BunNing, J. \& HAgeman, R. (1967). Intracellular localization of nitrate reductase, nitrite reductase and glutamic acid dehydrogenase in green leaf tissue. $P l$. Physiol., Lancaster 42, 233.

RoDRIGUEZ-LOPEZ, M. (1966). Utilization of sugars by Chlorrella under various conditions. J. gen. Microbiol. 43, 139.

SYRETT, P. J. (1955). The assimilation of ammonia and nitrate by nitrogen starved cells of Chlorella vulgaris. I. The assimilation of small quantities of nitrogen. Physiologia Pl. 9, 19.

TAYLOR, F. J. (1950). Oxidative assimilation of glucose by Scenedesmus quadriculata. J. exp. Bot. I, 301.

22

G. Microb. 54 
VAN Niel, C. B., Allen, M. B. \& Wright, B. (1953). On the photochemical reduction of nitrate by algae. Biochim. Biophys. Acta 12, 67.

WARBURG, O. \& KRIPPAHL, G. (1959). Weiterentwicklung der Manometrischen Methoden. Z. Naturf. $\mathbf{1 4} b, 561$.

WARBURG, O. \& KRIPPAHL, G. (I960). Notwendigkeit der Kohlensäure für die Chinon und Ferricyanid-Reaktion in grïnen Grana. $Z$. Naturf. $15 b, 367$.

Warburg, O. \& Negelein, E. (1920). Über die Reduktion der Saltpetersäure in grünen Zellen. Biochem. Z. Iro, 66. 